\title{
Comparison of hemodynamic responses to endotracheal intubation with the GlideScope video laryngoscope and Macintosh laryngoscope in patients undergoing cardiovascular surgery
}

\author{
Kardiyovasküler cerrahi hastalarında GlideScope video laringoskop ve \\ Macintosh laringoskopun endotrakeal entübasyona hemodinamik yanıtlarının karşılaştırılması
}

\author{
Gökhan İnangil $₫$, Kadir Hakan Cansız $₫$, Fuat Gürbüz $₫$, Ömer Bakal ${ }^{\circ}$, Fatma Merih Gökben $₫$, Hüseyin Şen $₫$ \\ Department of Anesthesiology and Reanimation, \\ University of Health Sciences, Sultan Abdülhamid Han Training and Research Hospital, İstanbul, Turkey
}

\begin{abstract}
Background: This study aimed to compare hemodynamic response to endotracheal intubation using GlideScope and Macintosh laryngoscopes in patients who underwent cardiovascular surgery.

Methods: A total of 74 patients were enrolled in the study. Patients were randomly assigned into two groups either a GlideScope $(n=37)$ or a Macintosh laryngoscope $(n=37)$. Laryngoscopy time, heart rate, invasive arterial pressure and rate pressure product were compared during induction and until five minutes after laryngoscopy at 11 time points.

Results: Seventy patients completed the study. The intubation time was similar in both groups $(14.1 \pm 4.0 \mathrm{sec}$ vs. $13.2 \pm 4.2 \mathrm{sec}$; $\mathrm{p}=0.22$ ). Hemodynamic values including heart rate, systolic, diastolic and mean arterial pressure and rate pressure product were similar at all-time points. The laryngoscopy time was also similar between groups.
\end{abstract}

Conclusion: The GlideScope video laryngoscope did not show any advantage on hemodynamic response in patients undergoing cardiovascular surgery when compared to Macintosh laryngoscope.

Keywords: Cardiovascular surgery; GlideScope; hemodynamic response; intubation; laryngoscopy.

Both laryngoscopy and endotracheal intubation cause hypertension, tachycardia, or arrhythmia as a result of sympathetic stimulation. These hemodynamic responses are short-term but may lead to hemodynamic instability and myocardial ischemia in patients with severe coronary artery disease..$^{[1-5]}$

\section{$\ddot{O} Z$}

Amaç: Bu çalışmada kardiyovasküler cerrahi uygulanacak hastalarda GlideScope ve Macintosh laringoskopile entübasyonun hemodinamik etkileri karşılaştırıldı.

Çalışma plant: Çalışmaya toplam 74 hasta alındı ve hastalar GlideScope $(n=37)$ ve Macintosh $(n=37)$ olarak rastgele iki gruba ayrıldı. Laringoskopi süresi, kalp atım hızı, invaziv arteriyel basınç ve nabız-basınç çarpanı verileri indüksiyon başlangıcından laringoskopi sonrası beşinci dakikaya kadar 11 farklı zamanda kaydedildi.

Bulgular: Yetmiş hasta çalışmayı tamamlayabildi. Entübasyon süreleri her iki grupta benzer olarak bulundu (14.1 \pm 4.0 saniye vs. $13.2 \pm 4.2$ saniye; $\mathrm{p}=0.22$ ). Kalp atım hızı, sistolik, diyastolik ve ortalama arter basınçları ve nabız-basınç çarpanı gibi hemodinamik veriler arasında tüm ölçüm noktalarında anlamlı fark bulunmadi. Laringoskopi süresi her iki grupta benzerdi.

Sonuç: GlideScope video laringoskop kardiyovasküler cerrahi uygulanacak hastalarda Macintosh laringoskop ile karşılaştırıldığında hemodinamik olarak avantaj sağlamadığı görüldü.

Anahtar sözcükler: Kardiyovasküler cerrahi; GlideScope; hemodinamik yanit; entübasyon; laringoskopi.

The curved laryngoscope blade presented by Macintosh in 1943 is still the most widely used device for endotracheal intubation and is based on the principle of direct visualization of glottis through line of sight. ${ }^{[6]}$ GlideScope ${ }^{\circledR}$ video laryngoscope (Portable GVL, Veraton Medical, Canada), which is designed for

Received: January 12, 2018 Accepted: April 23, 2018

Correspondence: Gökhan İnangil, MD. Sağlık Bilimleri Üniversitesi, Sultan Abdülhamid Han Eğitim ve Araştırma Hastanesi, Anestezi ve Reanimasyon Kliniği, 34668 Üsküdar, İstanbul, Turkey. Tel: +90 532 - 7739003 e-mail: ginangil2@gmail.com goscope and Macintosh laryngoscope in patients undergoing cardiovascular surgery. Turk Gogus Kalp Dama 2018;26(3):386-393. 
patients with difficult airways, has a blade angle of $60^{\circ}$ and a camera to visualize the glottis independent of the direct line of sight. ${ }^{[7-9]}$

The severity of the hemodynamic response during laryngoscopy is attributed to correlate with laryngoscopy time and the magnitude of manipulation to expose glottis. ${ }^{[10,11]}$ While using GlideScope, less upward lifting force is needed to expose the glottis than the conventional Macintosh blade and it is hypothesized that GlideScope may be associated with less hemodynamic response while providing better visualization of the larynx..$^{[12,13]}$ Many studies have compared the hemodynamic response of the GlideScope and Macintosh laryngoscope but results are conflicting. In majority of the studies, noninvasive blood pressure was used for hemodynamic monitoring which was a limitation since invasive arterial pressure monitoring provides more frequent and precise pressure readings.

Therefore we designed this randomized controlled study with standardized protocol for anesthesia and invasive arterial pressure monitoring to compare the hemodynamic response of endotracheal intubation with GlideScope and Macintosh laryngoscopes in patients undergoing cardiovascular surgery.

\section{PATIENTS AND METHODS}

After approval by the Medipol University, Medical Faculty Ethical Committee (Protocol 10840098604.01.01-E.5096/677, 23 Dec 2015, trial registration (ClinicalTrials.gov Identifier: NCT02708420 March 2016) and written informed consent, 74 American Society of Anesthesiologists (ASA) physical status III patients undergoing elective cardiovascular surgery were included. Patients with a history of difficult intubation or anticipated difficult intubation (short thyromental distance $[<6 \mathrm{~cm}]$ and inter-incisor distance $[<4 \mathrm{~cm}]$, reduced neck mobility, and a Mallampati score of III-IV) were excluded from study.

Preoperatively, patients received beta-blocker and angiotensin converting enzyme inhibitor or angiotensin II receptor blockers. Calcium channel blockers were discontinued preoperatively in all patients according to clinical regimen.

All patients received standardized general anesthesia according to our institutional regimen for cardiovascular surgery. Two hours before induction of anesthesia, patients were pre-medicated with diazepam (3.75-7.5 mg intramuscular). Standard monitoring, including 5 lead electrocardiogram, pulse oximetry,

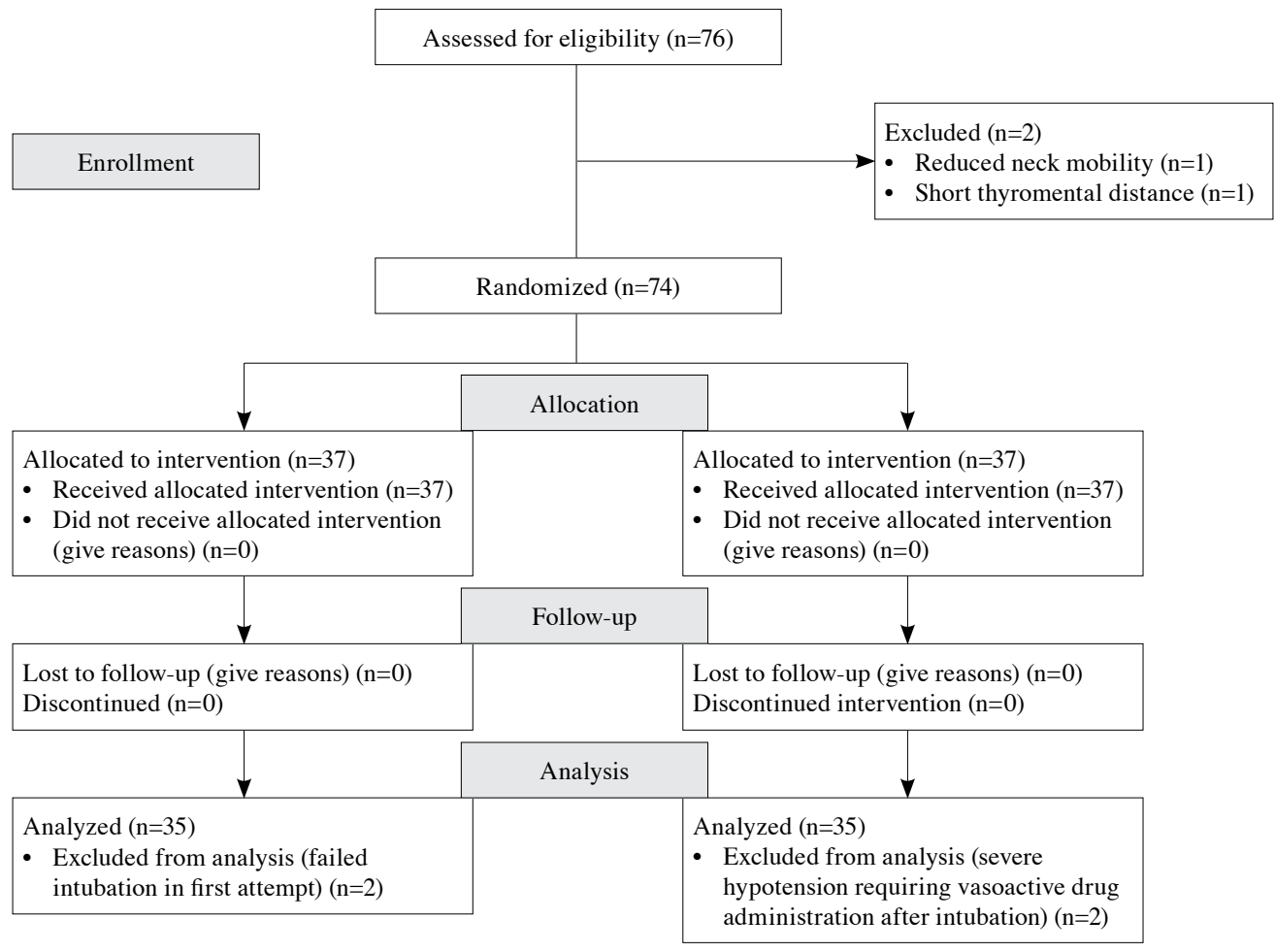

Figure 1. Consort of flow diagram of patient recruitment. 
Table 1. Demographic data of the patients

\begin{tabular}{|c|c|c|c|c|c|c|c|}
\hline & \multicolumn{3}{|c|}{ Macintosh $(\mathrm{n}=35)$} & \multicolumn{3}{|c|}{ GlideScope $(\mathrm{n}=35)$} & \multirow[b]{2}{*}{$p$} \\
\hline & $\mathrm{n}$ & $\%$ & Mean \pm SD & $\mathrm{n}$ & $\%$ & Mean \pm SD & \\
\hline Age (year) & & & $65.5 \pm 9.7$ & & & $64.2 \pm 7.8$ & 0.52 \\
\hline Gender & & & & & & & 0.40 \\
\hline Female & 10 & 7 & & & & & \\
\hline Male & 25 & 28 & & & & & \\
\hline Height (cm) & & & $168.9 \pm 7.4$ & & & $169.6 \pm 8.5$ & 0.71 \\
\hline Weight (kg) & & & $79.5 \pm 10.9$ & & & $79.5 \pm 10.8$ & 0.99 \\
\hline Body mass index $\left(\mathrm{kg} / \mathrm{m}^{2}\right)$ & & & $27.8 \pm 3.4$ & & & $27.8 \pm 4.4$ & 0.95 \\
\hline Mallampati score & & & & & & & 0.78 \\
\hline I & 26 & 74.3 & & 25 & 71.4 & & \\
\hline II & 9 & 25.7 & & 10 & 28.6 & & \\
\hline \multicolumn{8}{|l|}{ Preoperative medication } \\
\hline Beta blockers & 34 & 97.1 & & 33 & 94.3 & & 0.55 \\
\hline ACE inhibitors & 29 & 82.9 & & 28 & 80 & & 0.76 \\
\hline ARBs & 6 & 17.1 & & 7 & 20 & & 0.76 \\
\hline
\end{tabular}

SD: Standard deviation; ACE: Angiotensin-converting enzyme; ARBs: Angiotensin II receptor blockers.

non-invasive and invasive arterial blood pressure measurements (Datex Ohmeda S/5 Patient Anesthesia Monitor, GE Healthcare, Helsinki, Finland), was established prior to induction. During this process all patients were pre-oxygenated with a face mask at $6 \mathrm{~L} / \mathrm{min}$ oxygen flow and crystalloid infusion was initiated. Patients were randomly allocated to one of the groups based on computer generated random numbers that were sealed in an envelope. Anesthesia was induced with total dose of 4-6 $\mu \mathrm{g} / \mathrm{kg}$ fentanyl and $0.08-0.12 \mathrm{mg} / \mathrm{kg}$ midazolam throughout the induction period with divided doses considering hemodynamic response to avoid hypotension. Additionally $1 \mathrm{mg} / \mathrm{kg}$ intravenous lidocaine was administered during induction. After assisted bag valve ventilation, rocuronium bromide $0.6 \mathrm{mg} / \mathrm{kg}$ was administered for muscle relaxation and bag valve ventilation was continued for another two minutes. The patients' tracheas were intubated using the GlideScope or Macintosh laryngoscope with appropriate blade sizes. In the GlideScope group, specific pre-curved rigid stylet of GlideScope was used which was pre-lubricated for easy removal after intubation. Size 7.0 to $8.0 \mathrm{~mm}$ internal diameter polyvinyl chloride tracheal tube was preferred. Mechanical ventilation was initiated $\left(\mathrm{FiO}_{2} 0.5\right.$, VT $6 \mathrm{~mL} / \mathrm{kg}$, respiratory rate $12-14 / \mathrm{min}$ with $0.2 \%$ sevoflurane) after completion of intubation. Anesthesia was maintained with bolus doses of fentanyl and sevoflurane (0.4-1\%). All intubations were performed by the same anesthetist with experience in using both GlideScope and Macintosh laryngoscopes. In case of primary intubation failure, a second intubation attempt was performed after another period of mask ventilation and the patient would be excluded from study. In case of hypotension, the patient would be treated appropriately and excluded from the study.

Table 2. Comparison of laryngoscopy data of groups

\begin{tabular}{|c|c|c|c|c|c|}
\hline & \multicolumn{2}{|c|}{ Macintosh $(n=35)$} & \multicolumn{2}{|c|}{ GlideScope $(n=35)$} & \multirow[b]{2}{*}{$p$} \\
\hline & $\mathrm{n}$ & Mean \pm SD & $\mathrm{n}$ & Mean \pm SD & \\
\hline Cormack-Lehane Grade & & & & & 0.69 \\
\hline 1 & 24 & & 23 & & \\
\hline 2 & 7 & & 12 & & \\
\hline 3 & 4 & & 0 & & \\
\hline Cricoid pressure & 8 & & 7 & & 0.77 \\
\hline Jaw trust & 0 & & 0 & & \\
\hline Laryngoscopy time (seconds) & & $14.1 \pm 4.0$ & & $13.2 \pm 4.2$ & 0.22 \\
\hline
\end{tabular}


Intubation time was recorded with a stopwatch started by the passing of the GlideScope or Macintosh blade through the lips until the anesthetist notified that endotracheal tube was placed and the blade removed from patient mouth. Additionally, anesthetics used for induction of anesthesia, the quality of glottic view, maneuvers such as cricoid pressure or jaw trust, complications, and preoperative medications were also recorded. Glottic view during laryngoscopy was graded with Cormack-Lehane score for the Macintosh group and four points scale similar to CormackLehane score used for GlideScope with monitor image. All arterial pressures were measured invasively from the right radial artery. Hemodynamic data was recorded at 11 different time points: before induction of anesthesia $\left(\mathrm{T}_{1}\right)$ and during induction at one-minute intervals $\left(\mathrm{T}_{2-3}\right)$, just before laryngoscopy $\left(\mathrm{T}_{4}\right)$, and after intubation at 30 seconds intervals $\left(\mathrm{T}_{5-8}\right)$ until second $\left(T_{9}\right)$, fourth $\left(T_{10}\right)$ and fifth minutes $\left(T_{11}\right)$ by a blinded researcher through a secondary monitor. While recording hemodynamic values after intubation any neck or tube movement and patient positioning which may cause another sympathetic stimulation was avoided. After obtaining hemodynamic values, rate pressure product (RPP) was calculated as an index of myocardial oxygen consumption.

\section{Statistical analysis}

Statistical calculations were performed by SPSS version 15.0 software (SPSS Inc., Chicago, IL, USA). Sample size calculation was based on a pilot study. To detect a $10 \%$ change in heart rate and mean arterial pressure, 35 patients in each group were required to achieve a power of $80 \%$ at a 0.05 level of significance. Continuous variables were expressed as mean \pm standard deviation (SD). Categorical data was presented as numbers and percentages. Independent student t-test was used to compare variables with normal distribution (age, height, weight, body mass index), the Mann-Whitney $U$ test was applied for the evaluation of non-normally distributed data (laryngoscopy time). Chi-square or Fisher's exact test was used for evaluation of non-continuous variables. $\mathrm{P}<0.005$ was considered statistically significant.

\section{RESULTS}

Seventy patients completed the study. Two patients in the Macintosh group required a second attempt (the laryngoscope's light turned off in one and the second attempt was required with a stylet in the other) and severe hypotension requiring vasoactive drug administration after intubation occurred in two patients in the GlideScope group (Figure 1).

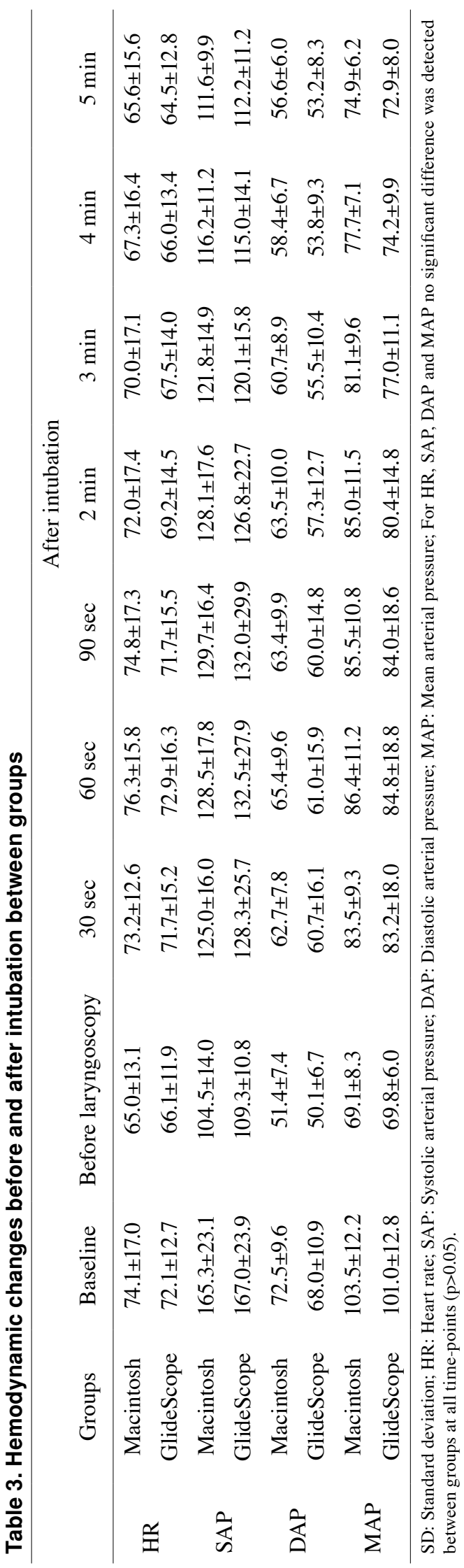




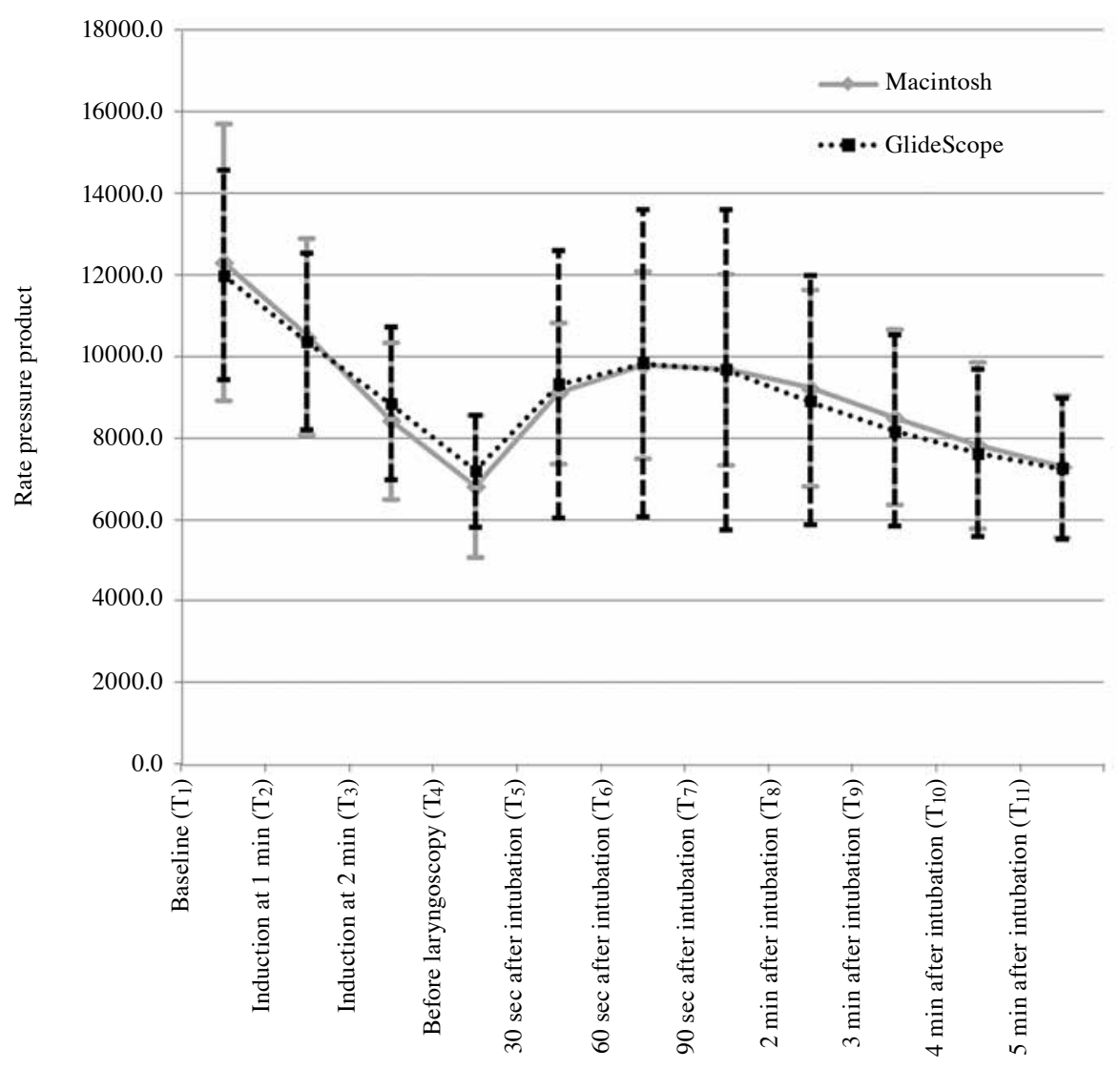

Figure 2. Changes of mean rate pressure product (RPP) between groups.

Data are Mean \pm SD. For RPP, no significant difference was detected between groups $(p>0.05)$.

There was no esophageal intubation in both groups. The patients' demographic data and preoperative medications were similar in both groups (Table 1). There was no significant difference in laryngoscopy time, application of cricoid pressure, and CormackLehane Grade between the groups ( $p>0.05)$ (Table 2). Hemodynamic values including heart rate, systolic, diastolic and mean arterial pressure (Table 3), and RPP were similar between groups at all-time points $(\mathrm{p}>0.05)$ (Figure 2).

\section{DISCUSSION}

During endotracheal intubation, both blood pressure and heart rate increases as a result of stimuli to oropharyngeal structures and the larynx with laryngoscopy, and stimulus to the trachea with the passage of endotracheal tube through vocal cords. These hemodynamic responses initiate within seconds of intubation, peaking in 1-2 minutes. ${ }^{[10,14]}$ Although they are short- termed, myocardial oxygen demand may increase and may lead to myocardial ischemia in patients with coronary artery disease. ${ }^{[15]}$ To prevent these adverse hemodynamic responses, different intubation methods, anesthetics, and adjuvant agents, have been studied. ${ }^{[3,4,15,16]}$

Lidocaine is an amid-type local anesthetic which is also classified as class IB antiarrhythmic drug, as it has antagonistic action on voltage-gated sodium channels. Lidocaine also inhibits N-methyl-D-aspartate (NMDA) receptors. ${ }^{[17]}$ Intravenous administration of lidocaine is recommended for reducing hemodynamic responses to intubation, attenuation of cough reflexes, and intracranial and intraocular pressure. ${ }^{[18]}$ Many studies have been conducted to reveal its effects on hemodynamic response to intubation. However dose of lidocaine varies from 1.5 to $2 \mathrm{mg} / \mathrm{kg} .{ }^{[17,18]}$ We preferred to use $0.5-1 \mathrm{mg} / \mathrm{kg}$ dose in our clinical practice for induction of anesthesia in both cardiac and non-cardiac surgery. In our study we preferred to use $1 \mathrm{mg} / \mathrm{kg}$ for induction for standardization. However, it should be considered that the magnitude and duration of hemodynamic response to intubation may differ from studies in which lidocaine was not used. 
A recent study found that during laryngoscopy with the Macintosh blade, the maximal force applied by the blade onto the base of tongue was 20 Newton (N) and the average force was $11 \mathrm{~N}$, measured by thin piezoresistive sensors attached to the distal concave surface of each laryngoscope. The median peak and average forces applied during GlideScope laryngoscopy were $57 \%$ and 53\%, respectively, lower than laryngoscopy performed with the Macintosh blade in the same study. ${ }^{[19]}$ As a result, when more lifting force is applied to optimize intubation with prolonged intubation time, a more adverse hemodynamic response is expected. ${ }^{[2,20]}$ The GlideScope is a video laryngoscope designed particularly for patients with difficult airways. With the special $60^{\circ}$ curved blade design, the GlideScope can reduce the mechanical stimulus to oropharyngeal and laryngeal structures as less upward lifting force is required to expose the glottis compared to Macintosh blade. As the maximal lifting force applied is suggested to be lower and less neck movement is required during laryngoscopy GlideScope may have advantage over Macintosh for attenuating hemodynamic response to endotracheal intubation. ${ }^{[21,22]}$ Although there are studies that have demonstrated that endotracheal intubation performed by GlideScope and other indirect laryngoscopy devices cause less hemodynamic responses, ${ }^{[11,23,24]}$ recent studies have shown that the hemodynamic responses of both devices are similar. In our study, there was no significant difference between the GlideScope and Macintosh groups in heart rate, systolic, mean and diastolic pressures, as well as RPP during the period of five minutes after endotracheal intubation in consistence with the majority of previous studies. ${ }^{[20,25-27]}$ These results suggest that the passage of the tracheal tube through the vocal cords and tracheal stimulus is the main cause of the hemodynamic response to endotracheal intubation. ${ }^{[2,22,26,28]}$ A majority of studies have demonstrated that laryngoscopy time was significantly longer in GlideScope however we found no significant difference between the groups in our study. Studies claim that longer intubation time in the GlideScope group may counterbalance the favorable effect of reduced laryngoscope lifting force. ${ }^{[2,29]}$ However, we achieved same results in our study without longer laryngoscopy time that supports the tracheal stimulus theory. ${ }^{[22,26,30]}$

Using GlideScope requires excellent eye-hand coordination because while the performer manipulates the stylet and endotracheal tube, the eyes look to a different location and the performer sees the resulting action only through the monitor. Rotation, withdrawal of the tracheal tube, aligning the tip of the endotracheal tube to the glottis, and positioning the blade can also increase the stimulus since GlideScope has a wider blade than Macintosh and therefore occupies more intraoral space which may require additional maneuvers for the passage of the tracheal tube. Finally, a pre-curved specific stylet compatible with the $60^{\circ}$ curve of GlideScope blade must be used and both advancement of tracheal tube and withdrawal of the stylet after intubation may cause a stimuli to the anterior commissure or anterior wall of trachea. ${ }^{[31]}$

Xue et al. ${ }^{[20]}$ studied the GlideScope and Macintosh laryngoscopes in ASA I patients and did not found significant advantage in terms of hemodynamic response to endotracheal intubation, while intubation time was significantly higher in the GlideScope group. They claimed that the manipulation of GlideScope stylet, may cause higher stimulus to the larynx and trachea, counterbalancing the lower upward lifting force required for laryngoscopy. Afterwards, Siddiqui et al. ${ }^{[25]}$ used the stylet in all groups to standardize the technique. They did not observe any difference in hemodynamic response between the groups and attributed this to the fact that tracheal stimulation was a major factor for hemodynamic response. . $^{[8,14,22,25,30]}$ Similarly, Pournajafian et al. ${ }^{[32]}$ also reported that no difference in hemodynamic responses in normotensive patients but they reported increased intubation time with GlideScope. Our results were consistent with these studies; however, laryngoscopy time was similar in both groups in our study. Xue et al. ${ }^{[20]}$ reported $28.4 \pm 1.7 \mathrm{sec}$ and $37.4 \pm 9.9 \mathrm{sec}$ respectively for Macintosh and GlideScope laryngoscopes while defining intubation time as "the period from the termination of manual ventilation using a face mask to the resuming of ventilation through a tracheal tube". Pournajafian et al. ${ }^{[32]}$ defined intubation time as "time from insertion of assigned intubating device into the mouth up to the time the tracheal tube positioned between vocal cords" and they reported $7.8 \pm 3.7 \mathrm{sec}$ and $15.9 \pm 6.6 \mathrm{sec}$ respectively for Macintosh and GlideScope laryngoscopes. However, the investigator in this study had no previous experience and had only performed 20 successful intubations with GlideScope under supervision before the study. As different studies defined intubation time independently, we preferred to use the term laryngoscopy time which is the period starting with the passing of the GlideScope or Macintosh blade through the lips and ending when the blade is removed from the patient's mouth. In our study, all intubations were performed by the same investigator who had three years of experience with GlideScope which may attribute our relatively short laryngoscopy time with GlideScope. 
The RPP is an index of myocardial oxygen consumption. It is calculated by the multiplication of heart rate and systolic blood pressure and was previously used during exercise testing. ${ }^{[33]}$ Rate pressure product was used in our study because it briefly indicates hemodynamic response including both heart rate and systolic arterial pressure which we expected to rise following intubation. In our study, RPP values were similar between GlideScope and Macintosh groups at all-time points (Figure 3, Table 3).

Our study had several limitations. Firstly, patients with anticipated difficult airways were not involved in our study. Longer laryngoscopy time with more upwards lifting force with Macintosh laryngoscope may further increase hemodynamic response. Secondly, only the observer collecting hemodynamic data was blinded to the laryngoscopy method as it was impossible to blind the operator performing laryngoscopy. Thirdly, anesthesia induction was induced with moderately high dose fentanyl, midazolam, and $1 \mathrm{mg} / \mathrm{kg}$ lidocaine which may suppress hemodynamic response and cannot be generalized for non-cardiac surgery population in routine anesthesia practice. Despite these limitations, our study had favorable features; invasive arterial monitoring provided more frequent and precise pressure readings during our study so hemodynamic response was obtained in 30-second intervals within the first two minutes when peak hemodynamic response is expected.

In conclusion, GlideScope video laryngoscopy did not show any advantage when compared to Macintosh laryngoscope in terms of hemodynamic response in patients undergoing cardiovascular surgery. The laryngoscopy time was also similar between groups.

\section{Declaration of conflicting interests}

The authors declared no conflicts of interest with respect to the authorship and/or publication of this article.

\section{Funding}

The authors received no financial support for the research and/or authorship of this article.

\section{REFERENCES}

1. Sameenakousar, Mahesh, Srinivasan KV. Comparison of fentanyl and clonidine for attenuation of the haemodynamic response to laryngocopy and endotracheal intubation. J Clin Diagn Res 2013;7:106-11.

2. Shribman AJ, Smith G, Achola KJ. Cardiovascular and catecholamine responses to laryngoscopy with and without tracheal intubation. Br J Anaesth 1987;59:295-9.

3. Kovac AL. Controlling the hemodynamic response to laryngoscopy and endotracheal intubation. J Clin Anesth 1996;8:63-79.
4. Kahl M, Eberhart LH, Behnke H, Sänger S, Schwarz U, Vogt $\mathrm{S}$, et al. Stress response to tracheal intubation in patients undergoing coronary artery surgery: direct laryngoscopy versus an intubating laryngeal mask airway. J Cardiothorac Vasc Anesth 2004;18:275-80.

5. Ezri T, Weisenberg M, Khazin V, Zabeeda D, Sasson L, Shachner A, et al. Difficult laryngoscopy: incidence and predictors in patients undergoing coronary artery bypass surgery versus general surgery patients. J Cardiothorac Vasc Anesth 2003;17:321-4.

6. Schälte G, Scheid U, Rex S, Coburn M, Fiedler B, Rossaint $\mathrm{R}$, et al. The use of the Airtraq ${ }^{\circledR}$ optical laryngoscope for routine tracheal intubation in high-risk cardio-surgical patients. BMC Res Notes 2011;4:425.

7. Huang WT, Huang CY, Chung YT. Clinical comparisons between GlideScope video laryngoscope and Trachlight in simulated cervical spine instability. J Clin Anesth 2007;19:110-4.

8. Malik MA, Maharaj CH, Harte BH, Laffey JG. Comparison of Macintosh, Truview EVO2, Glidescope, and Airwayscope laryngoscope use in patients with cervical spine immobilization. Br J Anaesth 2008;101:723-30.

9. Xue FS, Zhang GH, Liu J, Li XY, Yang QY, Xu YC, et al. The clinical assessment of Glidescope in orotracheal intubation under general anesthesia. Minerva Anestesiol 2007;73:451-7.

10. Güzelmeriç F, Erdoğan HB, Koçak T. Anesthesiologic approach to cardiac emergencies. Turk Gogus Kalp Dama 2007;15:82-9.

11. Kihara S, Brimacombe J, Yaguchi Y, Watanabe S, Taguchi N, Komatsuzaki T. Hemodynamic responses among three tracheal intubation devices in normotensive and hypertensive patients. Anesth Analg 2003;96:890-5.

12. Rai MR, Dering A, Verghese C. The Glidescope system: a clinical assessment of performance. Anaesthesia 2005;60:60-4.

13. Cooper RM, Pacey JA, Bishop MJ, McCluskey SA. Early clinical experience with a new videolaryngoscope (GlideScope) in 728 patients. Can J Anaesth 2005;52:191-8.

14. Adachi YU, Satomoto M, Higuchi H, Watanabe K. Fentanyl attenuates the hemodynamic response to endotracheal intubation more than the response to laryngoscopy. Anesth Analg 2002;95:233-7.

15. Gümüş F, Şinikoğlu SN, Yektaş A, Polat A, Kayalar N, Eralp K, et al. Dexmedetomidine combined with narcotic anesthesia induction in coronary artery bypass graft surgery. Turk Gogus Kalp Dama 2013;21:676-82.

16. Yazıcıŏ̆lu H, Özgök A, Balaban F, Doğanay B, Ünver S. Single dose esmolol attenuates bispectral index scale response to intubation during fentanyl-midazolam anesthesia for cardiac surgery. Turk Gogus Kalp Dama 2012;20:72-8.

17. Mendonça FT, de Queiroz LM, Guimarães CC, Xavier AC. Effects of lidocaine and magnesium sulfate in attenuating hemodynamic response to tracheal intubation: singlecenter, prospective, double-blind, randomized study. Braz J Anesthesiol 2017;67:50-6.

18. Hashemian AM, Zamani Moghadam Doloo H, Saadatfar M, Moallem R, Moradifar M, Faramarzi R, et al. Effects of intravenous administration of fentanyl and lidocaine on 
hemodynamic responses following endotracheal intubation. Am J Emerg Med 2018;36:197-201.

19. Russell T, Khan S, Elman J, Katznelson R, Cooper RM. Measurement of forces applied during Macintosh direct laryngoscopy compared with GlideScope ${ }^{\circledR}$ videolaryngoscopy. Anaesthesia 2012;67:626-31.

20. Xue FS, Zhang GH, Li XY, Sun HT, Li P, Li CW, et al. Comparison of hemodynamic responses to orotracheal intubation with the GlideScope videolaryngoscope and the Macintosh direct laryngoscope. J Clin Anesth 2007;19:245-50.

21. Sun DA, Warriner CB, Parsons DG, Klein R, Umedaly HS, Moult M. The GlideScope Video Laryngoscope: randomized clinical trial in 200 patients. Br J Anaesth 2005;94:381-4.

22. Adachi YU, Takamatsu I, Watanabe K, Uchihashi Y, Higuchi $\mathrm{H}$, Satoh T. Evaluation of the cardiovascular responses to fiberoptic orotracheal intubation with television monitoring: comparison with conventional direct laryngoscopy. J Clin Anesth 2000;12:503-8.

23. Mahjoubifar M, Boroojeny SB. Hemodynamic changes during orotracheal intubation with the glidescope and direct laryngoscope. Iran Red Crescent Med J 2010;12:406-8.

24. Dashti M, Amini S, Azarfarin R, Totonchi Z, Hatami M. Hemodynamic changes following endotracheal intubation with glidescope(®) video-laryngoscope in patients with untreated hypertension. Res Cardiovasc Med 2014;3:17598.

25. Siddiqui N, Katznelson R, Friedman Z. Heart rate/blood pressure response and airway morbidity following tracheal intubation with direct laryngoscopy, GlideScope and Trachlight: a randomized control trial. Eur J Anaesthesiol 2009;26:740-5.

26. Hirabayashi Y, Hiruta M, Kawakami T, Inoue S, Fukuda H,
Saitoh K, et al. Effects of lightwand (Trachlight) compared with direct laryngoscopy on circulatory responses to tracheal intubation. Br J Anaesth 1998;81:253-5.

27. Malik MA, Subramaniam R, Maharaj CH, Harte BH, Laffey JG. Randomized controlled trial of the Pentax AWS, Glidescope, and Macintosh laryngoscopes in predicted difficult intubation. Br J Anaesth 2009;103:761-8.

28. Kanchi M, Nair HC, Banakal S, Murthy K, Murugesan C. Haemodynamic response to endotracheal intubation in coronary artery disease: Direct versus video laryngoscopy. Indian J Anaesth 2011;55:260-5.

29. Bucx MJ, van Geel RT, Scheck PA, Stijnen T. Cardiovascular effects of forces applied during laryngoscopy. The importance of tracheal intubation. Anaesthesia 1992;47:1029-33.

30. Takahashi S, Mizutani T, Miyabe M, Toyooka $H$. Hemodynamic responses to tracheal intubation with laryngoscope versus lightwand intubating device (Trachlight) in adults with normal airway. Anesth Analg 2002;95:480-4.

31. Corda DM, Riutort KT, Leone AJ, Qureshi MK, Heckman MG, Brull SJ. Effect of jaw thrust and cricoid pressure maneuvers on glottic visualization during GlideScope videolaryngoscopy. J Anesth 2012;26:362-8.

32. Pournajafian AR, Ghodraty MR, Faiz SH, Rahimzadeh P, Goodarzynejad H, Dogmehchi E. Comparing GlideScope Video Laryngoscope and Macintosh Laryngoscope Regarding Hemodynamic Responses During Orotracheal Intubation: A Randomized Controlled Trial. Iran Red Crescent Med J 2014;16:12334.

33. Nelson RR, Gobel FL, Jorgensen CR, Wang K, Wang Y, Taylor HL. Hemodynamic predictors of myocardial oxygen consumption during static and dynamic exercise. Circulation 1974;50:1179-89. 